\title{
ORAL HEALTH STATUS OF 6- AND 12-YEAR-OLD CHILDREN OF ROMA ORIGIN FROM EASTERN SLOVAKIA: A PILOT STUDY
}

\author{
Zuzana Pilát, Jana Gal'ová, Eva Petrejčíková, Matúš Mathia, Iveta Boroňová, Jarmila Bernasovská \\ Department of Biology, Faculty of Humanities and Natural Sciences, University of Presov in Presov, Presov, Slovak Republic
}

\section{SUMMARY}

Objective: The purpose of this study was to determine the prevalence and clinical effect of untreated dental caries in Roma children from eastern Slovakia using dmft/DMFT index and SiC index, association between dental caries development and oral hygiene, dietary habits and preventive dental care.

Methods: Dental caries were assessed by recording the dmft index (for primary dentition) and the DMFT index (for permanent dentition) that are used to assess the state of teeth, which expresses the current state of teeth or its development in an individual or the entire population. The SiC index was calculated as the mean dmft of one-third of the population with highest caries scores. The normality of data distribution was tested by Shapiro-Wilk test. P-value $<0.05$ was considered statistically significant. Chi-square test was used to compare proportions (oral hygiene, dietary habits and preventive dental visit). Data were analysed using ordered logistic regression and t-test. The study includes questionnaire containing 5 questions about dietary habits, oral hygiene and preventive dental visit.

Results: The results of presented study confirmed higher average values of DMFT (3.24) in the population of 12-year-old Roma children and lower average values of $\mathrm{dmft}(2.5)$ in the second group $(p<0.05)$. The value of $\mathrm{SiC}$ index represented 6.10 in the group of six-year-old and 7.66 in twelve-year-old children. Logistic regression was performed to test the magnitude of the association between dental caries and related factors. There was statistically significant association between average value dmft/DMFT and dietary habits, oral hygiene, and preventive dental visit in both study groups.

Conclusion: The study revealed insufficient oral hygiene of the Roma children population. Systematic implementation of preventive examinations for oral hygiene and health programmes are needed to promote oral health. The study represents a pilot study of the SiC index values in Roma minority population from eastern Slovakia.

Key words: dmft index, SiC index, dental caries, primary dentition, permanent dentition

Address for correspondence: Z. Pilát, Department of Biology, Faculty of Humanities and Natural Sciences, University of Presov, 17th November 1, 081 16, Presov, Slovak Republic. E-mail: zuzanka.midova@gmail.com

https://doi.org/10.21101/cejph.a6225

\section{INTRODUCTION}

The World Health Organization (WHO) provided the definition of health, according to which health is a state of complete physi$\mathrm{cal}$, mental and social well-being. Oral health is an integral part of overall health of human organism, and it means healthy teeth and surrounding tissues, i.e., quality state of individual's teeth (1). Dental caries occurrence represents a specific issue of oral health. In general, the majority of oral diseases is of complex nature and results from infectious microbial agents, inborn and environmental factors (2). Dental caries affects a majority of children and adults worldwide, and represents a major public health problem due to the fact that disease burden and associated concomitants (pain, tooth loss, trouble learning, eating, and sleeping, days of missed school/work, emergency room visits) are concentrated in vulnerable populations such as racial and ethnic minorities, and those living in rural areas and in poverty (3).

Excessive intake of free carbohydrates, inadequate exposure to fluorides and without regular removal of microbial biofilm lead to destruction of the tooth structure, resulting in the appearance of pain. Lack of oral hygiene affects the quality of life associated with oral health, and in the advanced stage there is a loss of teeth, loss of dental pulp vitality, systemic infection and other pathological manifestations in the orofacial area $(4,5)$.

Roma minority population living in eastern Slovakia has certain characteristic features that differ from the Slovak majority population. These differences have a significant impact on their health status, including dental status (6-10). Oral health is influenced by both medical and preventive care. Medical care remedies the consequences of dental diseases, but cannot prevent them, where, on the other hand, preventive measures can handle it.

\section{MATERIALS AND METHODS}

In this study a total of 659 children (both genders) were enrolled, including 344 6-year-old probands and 315 12-year-old probands of Roma origin living in socially deprived area in the 
East region of Slovakia (Kežmarok-Podhorany, Červenica, Svinia, Šarišské Michal'any, Košice - Lunik IX). Children were divided into two groups with primary (6-year-old) and permanent dentition (12-year-old). The dental examinations were performed in every subject. Caries experience data (DMFT/dmft) was collected according to established protocols. DMFT/dmft scores were evaluated according to the WHO criteria (11). Oral examinations were carried out in classrooms with the help of a plain mirror and the ballpoint probe under daylight or, when necessary, using a portable source of light. The same examiner performed all examinations. No radiographs were taken. The written consent was signed by the children's parents or caregivers. All study protocols for participant recruitment and data collection were approved by the institutional Review Board and by the institutional Ethics Committee.

In Slovakia, the dmft index (for primary dentition) and the DMFT index (for permanent dentition) are used to assess the state of teeth, which expresses the current state of teeth or its development in an individual or the entire population. The cariosity of the primary and permanent teeth was evaluated using the dmft/ DMFT index, i.e., mean value per 1 individual, sum of decayed (d), missing (m) and filled (f) teeth. The SiC index was calculated as the mean dmft of one-third of the population with highest caries scores. Finally, the obtained value constituted the SiC Index. The normality of data distribution was tested by Shapiro-Wilk test. The Chi-square test was used for comparison of categorical variables and the t-test was used for the comparison of continuous variables between the two groups. $\mathrm{P}$-value $<0.05$ was considered statistically significant. The study includes questionnaire containing 5 questions about dietary habits, oral hygiene and preventive dental visit. The interviewer asked the participants to answer each question (Table 1). The questionnaire was designed to be computer readable and all answers from the respondents were collected using this digital system. Ordered logistic regression estimates relationships between an ordinal dependent variable and one or more categorical or continuous explanatory variables. In addition, the odds ratio of the relationships was calculated (Table 2). The statistical software STATISTICA 13.5 was used for data processing.

\section{RESULTS}

The study revealed that $46.5 \%$ of six-year-old Roma children brush their teeth without toothpaste, with 172 probands in the group of twelve-year-old having the most common response to the frequency of dental brushing once a day $(54.6 \%)\left(\chi^{2}=23.09\right.$; $\mathrm{p}<0.001)$. A specific issue for children at school age is an excessive intake of sweetened drinks and consumption of sweets leading to a caries process. For this reason, we focused on drinking sweetened drinks as well as eating sweets. As many as 296 (86\%) children from the 6-year-old Roma group drink sweetened drinks one to three times a day, but respondents from the 12-year-old Roma group responded up to 13 times more often $\left(\chi^{2}=31.73 ; p<0.001\right)$. In this respect, tooth decay is a rapid process, particularly in individuals who are neglecting dental hygiene and consuming fermentable sugars. In the sixyear-old group, up to $318(92.4 \%)$ consume sweets daily, while in the twelve-year-old group, 292 individuals (92.6\%) consume sweets each day $\left(\chi^{2}=0.02 ; p=0.900\right)$. The lack of knowledge of dental care also causes failure in annual preventive check-ups at the dentist. Only $5.3 \%$ of children in the twelve-year-old group underwent a preventive check-up, while 53 probands in the

Table 1. Dental care in 6- and 12-year-old Roma children $(N=659)$

\begin{tabular}{|c|c|c|c|c|c|}
\hline \multirow[t]{2}{*}{ Variable } & \multicolumn{2}{|c|}{$\begin{array}{l}\text { 6-year-old children } \\
\qquad(n=344)\end{array}$} & \multicolumn{2}{|c|}{$\begin{array}{l}\text { 12-year-old children } \\
(n=315)\end{array}$} & \multirow[t]{2}{*}{$\mathrm{p}$-value } \\
\hline & $\mathrm{n}$ & $\%$ & $\mathrm{n}$ & $\%$ & \\
\hline \multicolumn{6}{|l|}{ Brushing teeth } \\
\hline Brushing without toothpaste & 160 & 46.5 & 143 & 45.3 & \multirow{3}{*}{$<0.001$} \\
\hline Once a day (with toothpaste) & 161 & 46.8 & 172 & 54.6 & \\
\hline Twice a day (with toothpaste) & 23 & 6.6 & - & - & \\
\hline \multicolumn{6}{|l|}{ Drinking sweetened drinks } \\
\hline One to three times a day & 296 & 86.0 & 309 & 98.0 & \multirow{2}{*}{$<0.001$} \\
\hline More than three times a day & 48 & 13.9 & 6 & 1.9 & \\
\hline \multicolumn{6}{|l|}{ Drinking unsweetened drinks } \\
\hline One to three times a day & 310 & 90.1 & 240 & 76.1 & \multirow{2}{*}{$<0.001$} \\
\hline More than three times a day & 34 & 9.8 & 75 & 23.8 & \\
\hline \multicolumn{6}{|l|}{ Consumption of sweets } \\
\hline Once a week & 26 & 7.5 & 23 & 7.3 & \multirow{3}{*}{0.900} \\
\hline Daily & 318 & 92.4 & 292 & 92.6 & \\
\hline Exceptionally & - & - & - & - & \\
\hline \multicolumn{6}{|l|}{ Preventive dental visit } \\
\hline Yes & 53 & 15.4 & 17 & 5.3 & \multirow{2}{*}{$<0.001$} \\
\hline No & 291 & 84.5 & 298 & 94.6 & \\
\hline
\end{tabular}


six-year-old group underwent a preventive check-up $\left(\chi^{2}=17.35\right.$; $\mathrm{p}<0.001$ ) (Table 1).

Higher DMFT values may be due to the lifestyle and nutritional regimes, as Roma children involved in our study have a low economic and social status. Another prerequisite for higher caries index is an excessive intake of fermentable sugars and consequent tooth decay (Table 1).

In Table 2 the risk assessment takes into account caries status and oral hygiene, dietary habits, and preventive dental visits with present or absent dental caries in 6- and 12-year-old children. As for the oral hygiene practices and dental caries of 6-year-old children there was a statistically significant difference between the mode of cleaning and the prevalence of caries $(p<0.001)$. It was inferred that 6 -year-old Roma children who brush teeth with toothpaste once a day were at 1.2 times higher risk of developing dental caries as compared to children who brush teeth with toothpaste twice a day and without toothpaste $(\mathrm{OR}=1.20,95 \%$ CI: $0.20-1.45)$. We observed very similar results in the second study group -12 -year-old Roma children $(\mathrm{p}<0.001)$. The odds ratio of getting caries was 4.09 times higher in children who brush teeth with toothpaste once a day $(\mathrm{OR}=4.09,95 \% \mathrm{CI}$ : 3.63-4.55).
When comparing another factor that is involved in the development of dental caries, 6-year-old children who drink sweetened drinks one to three times a day were found to be at 1.65 times higher risk of developing caries $(p<0.001)$. In the second study group, there was a statistically significant difference $(\mathrm{p}<0.001)$ between children who drink sweetened drinks and the development of tooth decay $(\mathrm{OR}=11.75,95 \% \mathrm{CI}$ : 9.46-14.57).

Consumptions of sweets and dental caries - the odds of getting caries was 0.13 times lower in 6- year-old Roma children who consumed it once a week compared to 6-year-old Roma children who consumed sweets daily $(\mathrm{OR}=0.13,95 \% \mathrm{CI}$ : $0.06-0.28$, $\mathrm{p}<0.001)$. Comparing the consumption of sweets and caries prevalence in the second study group it was inferred that children who consumed sweets daily were at 3.19 times higher risk of caries process $(\mathrm{OR}=3.19,95 \% \mathrm{CI}: 1.80-4.58, \mathrm{p}<0.001)$.

Preventive dental visit and dental caries of 6-year-old children - there was a statistically significant difference between passing a preventive dental visit and developing tooth decay $(p<0.001)$ in both study groups of Roma children. The severity of dental caries was also found to be high in children who did not get preventive dental care $(\mathrm{dmft}=2.82, \mathrm{OR}=0.94,95 \% \mathrm{CI}: 0.52-1.71)$. In the

Table 2. Risk assessment caries status and oral hygiene, dietary habits, and preventive dental visits in 6- and 12-year-old children $(N=659)$

\begin{tabular}{|c|c|c|c|c|c|c|c|c|c|c|c|c|c|c|}
\hline \multirow{4}{*}{ Factors } & \multicolumn{7}{|c|}{$\begin{array}{l}\text { 6-year-old children } \\
\quad(n=344)\end{array}$} & \multicolumn{7}{|c|}{$\begin{array}{l}\text { 12-year-old children } \\
\qquad(n=315)\end{array}$} \\
\hline & \multirow{3}{*}{ Total } & \multicolumn{4}{|c|}{ Dental Caries } & \multicolumn{2}{|c|}{$\mathrm{dmft}$} & \multirow{3}{*}{ Total } & \multicolumn{4}{|c|}{ Dental Caries } & \multicolumn{2}{|c|}{ DMFT } \\
\hline & & \multicolumn{2}{|c|}{ Present } & \multicolumn{2}{|c|}{ Absent } & \multirow{2}{*}{ Mean } & \multirow{2}{*}{ SD } & & \multicolumn{2}{|c|}{ Present } & \multicolumn{2}{|c|}{ Absent } & \multirow{2}{*}{ Mean } & \multirow{2}{*}{ SD } \\
\hline & & $\mathrm{n}$ & $\%$ & $\mathrm{n}$ & $\%$ & & & & $\mathrm{n}$ & $\%$ & $\mathrm{n}$ & $\%$ & & \\
\hline \multicolumn{15}{|l|}{ Brushing teeth } \\
\hline $\begin{array}{l}\text { Brushing without } \\
\text { toothpaste }\end{array}$ & 160 & 116 & 72.5 & 43 & 26.8 & 1.7 & 1.3 & 143 & 80 & 56 & 63 & 44 & 1 & 1.1 \\
\hline $\begin{array}{l}\text { Once a day } \\
\text { (with toothpaste) }\end{array}$ & 161 & 78 & 48.4 & 84 & 51.6 & 3.4 & 3.9 & 172 & 122 & 70 & 50 & 30 & 5.8 & 4.2 \\
\hline \multirow[t]{2}{*}{$\begin{array}{l}\text { Twice a day } \\
\text { (with toothpaste) }\end{array}$} & 23 & 3 & 13 & 20 & 87 & 0.52 & 1.3 & & & & & & - & - \\
\hline & \multicolumn{5}{|c|}{$\mathrm{OR}=1.20,95 \% \mathrm{Cl}: 0.20-1.45$} & \multicolumn{2}{|c|}{$p<0.001$} & \multicolumn{5}{|c|}{$\mathrm{OR}=4.09,95 \% \mathrm{Cl}: 3.63-4.55$} & \multicolumn{2}{|c|}{$p<0.001$} \\
\hline \multicolumn{15}{|l|}{ Drinking sweetened drinks } \\
\hline $\begin{array}{l}\text { One to three times } \\
\text { a day }\end{array}$ & 296 & 188 & 63.5 & 108 & 36.5 & 2.54 & 2.7 & 309 & 196 & 63 & 113 & 37 & 2.9 & 3.2 \\
\hline \multirow[t]{2}{*}{$\begin{array}{l}\text { More than three times } \\
\text { a day }\end{array}$} & 48 & 9 & 18.7 & 39 & 81.3 & 2.25 & 4.7 & 6 & 6 & 100 & - & - & 17.7 & 3.9 \\
\hline & \multicolumn{5}{|c|}{$\mathrm{OR}=1.65,95 \% \mathrm{Cl}: 0.40-2.20$} & \multicolumn{2}{|c|}{$p<0.001$} & \multicolumn{5}{|c|}{$\mathrm{OR}=11.75,95 \% \mathrm{Cl}: 9.46-14.57$} & \multicolumn{2}{|c|}{$p<0.001$} \\
\hline \multicolumn{15}{|l|}{ Consumption of sweets } \\
\hline Once a week & 26 & 15 & 57.6 & 11 & 42.4 & 6.42 & 5.7 & 23 & - & - & 23 & 100 & 0 & 0 \\
\hline Daily & 318 & 182 & 57.2 & 136 & 42.7 & 2.18 & 2.5 & 292 & 202 & 69 & 90 & 31 & 3.5 & 3.8 \\
\hline \multirow[t]{2}{*}{ Exceptionally } & - & - & - & - & - & - & - & - & - & - & - & - & - & - \\
\hline & & $R=0.1$ & $95 \% \mathrm{C}$ & $06-0$. & & $p<0$ & & & $R=3.1$ & $55 \% \mathrm{C}$ & $80-4$. & & $p<0$ & \\
\hline Preventive dental visit & & & & & & & & & & & & & & \\
\hline Yes & 53 & 31 & 58.4 & 22 & 41.5 & 0.74 & 0.7 & 17 & 9 & 52 & 8 & 48 & 0.5 & 0.5 \\
\hline No & 291 & 166 & 57 & 125 & 43 & 2.82 & 3.2 & 298 & 193 & 65 & 105 & 35 & 3.4 & 3.8 \\
\hline & & $R=0.9$ & $95 \% \mathrm{C}$ & $52-1$. & & $p<0$ & & & $R=2.6$ & $55 \% \mathrm{C}$ & $97-4$. & & $p=0$ & 02 \\
\hline
\end{tabular}

$\mathrm{n}$ - number of subjects; SD - standard deviation; dependent variable: dmft/DMFT - decayed/missing/filled teeth in primary/permanent dentitions; independent variable: brushing teeth, drinking sweetened drinks, consumption of sweets, preventive dental visit; OR - odds ratio; $\mathrm{Cl}$ - confidence interval 
second study group the results were the opposite, the odds of developing dental caries was 2.62 times higher in children with preventive dental care $(\mathrm{dmft}=0.5, \mathrm{OR}=2.62,95 \% \mathrm{CI}$ : 0.97-4.27).

We then compared the values of the dmft/DMFT index and the Significant Caries Index ( $\mathrm{SiC}$ ) between the group of six- and twelve-year-old Roma children. The average cariosity index in the group of six-year-old Roma children was $2.5 \pm 3.071$, the $\mathrm{SiC}$ index was 6.10; the average cariosity index in the group of 12-year-old children was $3.2 \pm 3.832$ and the $\mathrm{SiC}$ index was $7.6 \pm 3.902$ (Table $3,4)$. The results show that 6 -year-old Roma children had a statistically significantly higher incidence of dental caries $(p<0.05)$, but when evaluating the $\mathrm{SiC}$ index, children from the 12-year-old group had statistically significantly worse dentition $(7.66, \mathrm{p}<0.05)$.

\section{DISCUSSION}

Tooth decay is a localized, pathological, destructive process of hard tooth tissues that occurs surficially beneath the surface of the enamel (12). Consumption of sweets, together with a microbial agent and a decrease in $\mathrm{pH}$, helps to create dental caries, which in the early stages appear on the enamel surface as a chalk spot (12). Temporary dentition is particularly susceptible to dental caries and, at the same time, there is a lower degree of mineralization, with a thick dentine layer and short dentine tubules leading to rapid dental caries spread (5).

Aetiology of dental caries has been related to a combination of environmental risk factors (oral hygiene, diet, fluoride exposure, etc.) and genetic predisposition (13). The earlier molecular genetic studies in humans focused on proline rich peptides in saliva and enamel formation genes (2).

In our study the results show that 6-year-old Roma children had a statistically significantly higher incidence of dental caries $(\mathrm{p}<0.05)$. For Slovakia, the average value of the carious index for 2017 is $\mathrm{dmft}=1.71$ (15). Biroš and Beluš in their study (7) report a cariosity index for six-year-old children $\mathrm{dmft}=0.7$ and

Table 3. Comparison of mean values of dmft/DMFT index in 6 - and 12-year-old Roma children $(N=659)$

\begin{tabular}{|l|c|c|c|}
\hline Study group & $\mathbf{n}$ & $\begin{array}{c}\text { dmft/DMFT } \\
\text { average value (SD) }\end{array}$ & p-value \\
\hline 6-year-old children & 344 & $2.5(3.071)$ & \multirow{2}{*}{0.006} \\
\hline 12-year-old children & 315 & $3.2(3.832)$ & \\
\cline { 1 - 3 } Whole study group & 659 & $2.85(3.473)$ & \\
\hline \multicolumn{2}{l|}{$n$-number of subjects; dmft/DMFT decayed/missing/filled teeth in primary/permanent } \\
\hline
\end{tabular}

dentitions; SD - standard deviation

Table 4. Comparison of mean values of SiC index in 6- and 12-year-old Roma children $(N=659)$

\begin{tabular}{|l|c|c|c|}
\hline Study group & $\mathbf{n}$ & $\begin{array}{c}\text { SiC index } \\
\text { average value (SD) }\end{array}$ & \multirow{2}{*}{$\mathbf{p}$-value } \\
\hline 6-year-old children & 344 & $6.10(2.930)$ & \multirow{2}{*}{$<0.001$} \\
\hline 12-year-old children & 315 & $7.66(3.902)$ & \\
\hline Whole study group & 659 & $6.89(3.754)$ & \\
\hline
\end{tabular}

$\mathrm{n}$ - number of subjects; SiC index - significant caries index in primary/permanent dentitions; SD - standard deviation for twelve-year-old children DMFT $=1.9$. When comparing our study with the study of Biroš and Beluš (7), we noticed that the $\mathrm{dmft}$ index in six-year-old children was higher by 1.8 in our study and in the 12-year-old DMFT group by 1.3 , respectively.

Socioeconomic opportunities and stereotypes in the Roma populations are manifested mainly in the consumption of unhealthy foods. 95\% of Roma menus are fatty cheap meat, animal and vegetable fats, excessive consumption of sweets and sweet drinks with a high content of simple carbohydrates, low consumption of fruits and vegetables, milk, and dairy products. From the point of view of a healthy diet, especially for children, the low consumption of fish, eggs, legumes, and vegetables is a significant unfavourable indicator. These important nutrition components are being replaced by bread and sweets (15). By examining the dentist's attendance in 2009 , it was found that out of the total number of individuals in the survey, $38.7 \%$ of Roma children did not visit the dentist at all. In the age group 10-15 years, $10.6 \%$ did not participate in the preventive dental examination. In the age group $0-9$ years it was $59 \%$ (15). Compared to our study, $58.4 \%$ of 6 -year-old children with dental caries and $52 \%$ of 12 -year-old children with DMFT higher than 1 underwent a preventive dental examination.

A specific issue for children in school age is excessive intake of sweetened drinks and consumption of sweets. This leads to the creation of incorrect eating habits and the development of dental caries (14). Tooth decay and periodontal disease are the most common chronic infections in the body. Oral diseases are highly prevalent, and their consequences are not only physical but also economic, social and psychological. Very important is the consistent prevention of tooth decay. The main objective in Europe is to develop full-value dental care, where the quality of prevention should be the most important factor in this regard (7, 15). Genetic factors and nutritional aspects are likely to play an important role in their oral health. Studies are currently underway to identify the needs of the Roma ethnic group. The obtained data serve as a basis for the implementation of preventive dental programmes, especially for Roma children $(7,15)$.

According to the National Health Information Centre (16) in Slovakia, the value of the DMFT index for 12-year-old children dropped from 2.2 in 2008 to 1.71 in 2017 onwards. The best states for dentition of 12-year-old children in this period are Austria, Denmark, Switzerland, and the United Kingdom (DMFT $<1$ ). In Romania, Moldova and Bulgaria, the index of caries was higher than 3 (17). The WHO has declared oral health objectives to reduce caries and its consequences. The aim of the WHO is that children aged twelve should not have a DMFT index higher than 3 (18). According to WHO data, SiC values were 5.6 DMFT in Austria, 4.7 in Australia, 7.3-7.7 in the Czech Republic, 8.1 in Trinidad, and 5.3-6.8 in Germany (19-22). To our knowledge there are no data available about the $\mathrm{SiC}$ values for primary and permanent teeth in children of Slovak majority or Roma minority population. Our study presents the results of the $\mathrm{SiC}$ values index in Roma minority population, which were set at 6.10 in six-yearold children and 7.66 in twelve-year-old children $(p<0.05)$.

\section{CONCLUSION}

This study represents a pilot study in Roma population highlighting dental caries in school children from eastern Slovakia. 
The study revealed insufficient oral hygiene of the Roma children. Systematic implementation of preventive examinations for oral hygiene and health programmes are needed to promote oral health.

\section{Acknowledgements}

This work was supported by the Grant Agency for PhD students and young scientists of University of Presov [GaPU 26/2019].

\section{Conflict of Interests}

None declared

\section{Adherence to Ethical Standards}

The study was approved by the Ethics Committee of Presov University, Faculty of Humanities and Natural sciences. All procedures performed in studies involving human participants were in accordance with the ethical standards of the institutional and/or national research committee and with the 1964 Helsinki Declaration and its later amendments or comparable ethical standards.

\section{REFERENCES}

1. World Health Organization. Constitution of the World Health Organization. Basic documents. 45 ed., supplement [Internet]. Geneva: WHO; 2006 [cited $2020 \mathrm{Feb}$ 13]. Available from: http://www.who.int/governance/eb/ who_constitution_en.pdf.

2. Patir A, Seymen F, Yildrim M, Deeley K, Cooper ME, Marazita ML, et al. Enamel formation genes are associated with high caries experience in Turkish children. Caries Res. 2008;42(5):394-400.

3. Shaffer JR, Carlson JC, Stanley BO, Feingold E, Cooper M, Vanyukov $\mathrm{MM}$, et al. Effect of enamel matrix genes on dental caries are moderated by fluoride exposures. Hum Genet. 2015;13(2):159-67.

4. Droppová K. Dental decay and paradentosis: research study. Košice: UPJŠ in Košice, Faculty of Natural Sciences; 2016. (In Slovak.)

5. Limeback H, editor. Comprehensive preventive dentistry. Prague: Grada; 2017. (In Czech)

6. Bernasovský I, Bernasovská J. Anthropology of Romanies (Gypsies): auxological and anthropogenetical study. Brno: Nauma; 1999.

7. Biroš $\mathrm{P}$, Beluš D. Oral health status of 6- and 12-year-old Romany children from east Slovakia. Slov Antropol. 2008;11(1):9-13.

8. Boroňová I, Bernasovský I, Bernasovská J. Detection of Down syndrome in the Roma and non-Roma populations of the Prešov catchment area in the period 1991-2003. In: Proceeding of the International Scientific Conference: 4. Biological Days; 2005 Sep 8-9; Nitra, Slovakia. Nitra: FPV UKF; 2005. p. 85-6. (In Slovak)

9. Boroňová I, Bernasovský I, Bernasovská J. Turner syndrome: cytogenetic findings in 24 patients from the Prešov region in Slovakia (1991 - 2003). Slov Antropol. 2005;8(2):37-41.

10. Boroňová I, Bernasovský I, Bernasovská J. Chromosome analysis in patients with MDS syndrome in the Prešov region (1995-2004). Slov Antropol. 2005;8(1):32-4. (In Slovak.)

11. World Health Organization. Oral health surveys: basic methods. 3rd ed. Geneva: WHO; 1987.

12. Seydlová M. Pedostomatology. Prague: Mladá fronta; 2015. (In Czech)

13. Borilova Linhartova P, Deissova T, Musilova K, Zackova L, Kukletova M, Kukla L, et al. Lack of association between ENAM gene polymorphism and dental caries in primary and permanent teeth in Czech children. Clin Oral Investig. 2017;22(4):1873-7.

14. Kožuchová M, Bašková M. Factors affecting dental hygiene in schoolaged children and adolescence. Ošetřovatelství a porodní asistence. 2012;3(2):369-74. (In Slovak.)

15. Popper M, Szeghy P, Šarkozy Š. Roma population and health: analysis of the situation in Slovakia. Bratislava: Partners for Democratic Change Slovakia; 2009. (In Slovak.)

16. National Health Information Center. Dental care in 2017 [Internet]. Bratislava: NHIC; 2018 [cited 2020 Feb 13]. Available from: http://data. nczisk.sk/statisticke_vystupy/Zubnolekarska_starostlivost/Zubnolekarska starostlivost_v_SR_2017.pdf . (In Slovak.)

17. National Health Information Center. Dental care in 2012 [Internet]. Bratislava: NHIC; 2013 [cited 2020 Feb 13]. Available from: http://www. nczisk.sk/Documents/publikacie/2012/zs1315.pdf. (In Slovak.)

18. FDI World Dental Federation. Annual Report 2018 [Internet]. Geneva: FDI; 2019 [cited $2020 \mathrm{Feb}$ 13]. Available from: https://www.fdiworlddental.org/resources/annual-reports/annual-report-2018.

19. Lencová E, Broukal Z, Mrklas L. Caries of upper deciduous incisors in 5-year-olds: an attempt at epidemiological definition of early childhood caries. Caries Res. 2002;36(3):204.

20. Momeni A, Pieper K, Stoll R. Decline in caries prevalence of 6- to 7-yearolds in Hesse in the years 1994 to 2000. Oralprophylaxe. 2002;24(3):99102. (In German.)

21. Städtler P, Bodenwinkler A, Sax G. Prevalence of caries in 6-year-old Austrian children. Oral Health Prev Dent. 2003;1(3):179-83.

22. Adewakun AA, Percival TM, Barclay SR, Amaechi BT. Caries status of children in eastern Trinidad, West Indies. Oral Health Prev Dent. 2005;3(4):249-61

Received April 10, 2020 Accepted in revised form November 10, 2020 